\title{
Wood Volume Production and Use of 10 Woody Species in Semiarid Zones of Northeastern Mexico
}

\author{
Rahim Foroughbakhch, ${ }^{1}$ Artemio Carrillo Parra, ${ }^{2}$ Jorge Luis Hernández Piñero, ${ }^{1}$ \\ Marco Antonio Alvarado Vázquez, ${ }^{1}$ Alejandra Rocha Estrada, ${ }^{1}$ and Ma Luisa Cardenas ${ }^{1}$
}

\author{
${ }^{1}$ Facultad de Ciencias Biologicas, Universidad Autonoma de Nuevo Leon, Apartado Postal F-2, \\ 66451 San Nicolas de los Garza, NL, Mexico \\ ${ }^{2}$ Facultad de Ciencias Forestales, Universidad Autonoma de Nuevo Leon, 67700 Linares, NL, Mexico
}

Correspondence should be addressed to Rahim Foroughbakhch, rahimforo@hotmail.com

Received 29 November 2011; Revised 26 March 2012; Accepted 29 March 2012

Academic Editor: Jingxin Wang

Copyright (C) 2012 Rahim Foroughbakhch et al. This is an open access article distributed under the Creative Commons Attribution License, which permits unrestricted use, distribution, and reproduction in any medium, provided the original work is properly cited.

A research strategy was established to analyze the structure of timber trees in terms of forest productivity (volume and wood density) of 10 species. The native species Acacia farnesiana, Acacia schaffneri, Bumelia celastrina, Cercidium macrun, Condalia hookeri, Ebenopsis ebano, Helietta parvifolia, and Prosopis laevigata and the exotic species Eucalyptus camaldulensis and Leucaena leucocephala were chosen due to their ecological and economic importance to the rural villages of northeastern Mexico. Measurements of different growth parameters and volume of trees were evaluated. The introduced species E. camaldulensis and L. leucocephala showed the best performance in wood volume production per tree and per hectare when compared to the native species. Likewise, among the native species, E. ebano, P. laevigata, C. hookeri, and A. farnesiana tended to show better characteristics in terms of wood volume production in comparison to H. parvifolia, A. schaffneri, C. macrum, and B. celastrina. Results showed a high diversity on the properties studied. The high biomass produced by most of the species considered in this study revealed their great energetic potential when used as wood and firewood or vegetal charcoal.

\section{Introduction}

Forest resources of Mexico rank third in importance in Latin America, covering more than 0.6 million $\mathrm{km}^{2}, 32.75 \%$ of the country area [1]. Eight different vegetation types have been described from northeastern Mexico. Among them, thornscrubs (low forest) are widely distributed under arid and semiarid conditions and also occurring in the high-altitude plateau. Seventy percent of this type of vegetation is located in areas suitable for rain-fed cropping and the rest in tropical and subtropical lowlands. Today all forest areas in Mexico cover less than a fifth of the national territory over an estimated area of less than 34 million ha with temperate and tropical lowland forests $[2,3]$. In northeastern Mexico the semiarid thornscrub vegetation extends over an area of about 20 million ha where 60 to 80 shrubs and tree species are found, some used by people living in the rural areas for either agriculture, livestock, or forest harvesting [4]. The obtained wood is mainly used for furniture, wagons, tool handles, and different kitchen utensils for rural households, as well as for firewood or charcoal [5-7]. A great number of studies regarding thornscrubs have been reported with frequent topics such as description of flowering patterns, germination rates, and fruit production as well as ecological interactions between microclimatic conditions, water relations, soil modification, and nitrogen fixation $[8,9]$. Concerning forestry management, the topics included are seed collecting and scarification, germination, pests and diseases, pruning, and species selection. A great number of studies on thornscrub have been reported, but a complete analysis of wood properties has been carried out for only a few species $[10,11]$. Thus, the main objective of the present research is to determine the forest potential of thornscrubs in terms of the physical properties of the wood of 10 timber species of major importance in the ecology and the economy of the arid and semiarid regions of northeastern Mexico and to establish a basis for 
better utilization of these species. Most of these species have a high atmospheric nitrogen fixation capacity, fast growth, shooting capacity, wood and firewood production capacity of high caloric value, and the capacity to grow successfully under a wide range of conditions $[12,13]$.

\section{Material and Methods}

2.1. Description of the Study Area. The experimental area is situated on a plain region at $400-600 \mathrm{~m}$ altitude in the piedmont of the Sierra Madre Oriental in Mexico (24 $47^{\prime \prime}$ north latitude and $99^{\circ} 32^{\prime \prime}$ west longitude). All the area is covered by the typical semiarid thornscrub dominated by woody plants which support cattle production and crops. The regional climate in the scheme of Köppen modified by García [14] is defined as semiarid and subhumid [(A) C (Wo)] with two rainy seasons (summer and autumn) and a dry spell between November and April. Mean annual precipitation is $780 \mathrm{~mm}$ [15]. The month with the largest mean rainfall is September (180-200 mm), and the lowest monthly registration occurs in December and January (15-20 mm). Average number of days with rain precipitation per year is $85 \pm 15$. About half of these days show precipitation amounts of $<5 \mathrm{~mm}$, mainly related to thunderstorms resulting from deep convection by midlatitude disturbances [16]. Coldfront systems generate most of the winter rainfall, accounting for $<10 \%$ of the long-term annual average. Potential evapotranspiration estimated by the Thornthwaite method is $-1150 \mathrm{~mm}$ [17]. The mean annual temperature is $22.3^{\circ} \mathrm{C}$ with a large difference between winter and summer (abs. $\min .12^{\circ} \mathrm{C}$, abs. max. $45^{\circ} \mathrm{C}$ ) and even within the same month. Hail and frosts usually occur each year even after the beginning of the growing season in March. The water budget is unbalanced. The ratio of precipitation to free evaporation is 0.48 and precipitation to potential evaporation is 0.62 .

Most soils of the region are of rocky type of Upper Cretaceous rich in calcite and dolomite. The dominant soils are deep, dark grey, lime-clay vertisols which are the result of alluvial and colluvial processes [18]. They are characterized by high clay and calcium carbonate content ( $\mathrm{pH}$ 7.0-8.0) and low organic matter content. Analysis of major nutrients reveals phosphorus and nitrogen deficiencies. Nitrogen is very volatile in the prevailing climate, and it is apparently lost when the vegetation is cleared from sites with diverse species of woody legumes, leaving the soil exposed to alternating conditions of heavy rain and extreme isolation. Such soils can be $3 \mathrm{~m}$ deep or more and are preferred for agricultural seepage. Underground water is hard but nonsaline.

Most plant species overlap vertically from 0.5 to $6.0 \mathrm{~m}$ $[19,20]$, and horizontally average distance between shrubby stems is $30 \mathrm{~cm}$ while mean crown radius is $47 \mathrm{~cm}$, resulting in a mean overlapping radius of $17 \mathrm{~cm}$. Average open space between shrub canopies is $10 \mathrm{~cm}$.

2.2. Species and Sample Trees. The 10 timber species used for this research were selected from those most preferred and used by the rural population because of their availability, high wood volume as timber for construction natural durability, and good construction quality [10,21].
Those harvested trees for high-quality craftsmanship were selected after their combination of beauty, working properties, and stability. Thus, 10 native and introduced species were considered.

Table 1 shows information about the name, family, and the wood characteristics of each of these species. Eight of the species used in the experiment are native to arid and semiarid zones in Mexico and adjacent USA territories. Eucalyptus camaldulensis and Leucaena leucocephala were also included in this investigation due to their importance as a naturalized species in the region.

The area of study covered 2,000 ha rich in wood arboreal and shrub vegetation with a density of 1,800 to 2,500 plants $\mathrm{ha}^{-1}$ according to the forest inventory carried out by Heiseke and Foroughbakhch [22]. Twenty plants from each of the eight native species considered as arboreal representatives of the local vegetation were selected through a stratified and random sampling. A previous growth ring count study [22] revealed that trees are currently 35 to 40 years old in average. For the naturalized wood species in this area (L. leucocephala and E. camaldulensis), plantations with representative trees around 35 years old were located next to the adjacent natural vegetation, and 20 individuals for each of the two species were selected at random. Results on the growth and yield parameters of native plants growing in nature were compared to the same parameters obtained in plantations of the same species in a monoculture system of about 30 years old. Thus, the experiment was evaluated on the basis of measurements of the following variables taken on 20 individuals per species: height increment (using a height pole), basal diameter BD (at $10 \mathrm{~cm}$ above the ground, using a diameter tape), diameter at breast height DBH (at $1.38 \mathrm{~m}$ above the ground, using a tree caliper), crown surface area $(C)$ which was determined by projecting the edges of the crown to the ground and measuring the length from edge to edge through the crown center along the North-South axis $(D 1)$ and East-West axis (D2) to enter the obtained values in the formula $C=[(D 1+$ $D 2) / 4] 2 * \pi[23]$, and firewood volume. All these parameters were estimated based in the age of the trees. Firewood volume $(V)$ was estimated by using the Smalian equation [24] based on each yield plant ${ }^{-1}$ species $^{-1}$ (standing without cutting the tree) taking into account all of those trunks with a length of $1.8 \mathrm{~m}$ or higher and $0.1 \mathrm{~m}$ in diameter in both upper and lower extremes or those individuals with diameter values at breast height equal to or greater than $0.1 \mathrm{~m}$, as it is considered a suitable commercial size for constructions in the rural areas in Mexico:

$$
V=\frac{\pi}{4\left[\left(D_{1}^{2}+D_{2}^{2}\right) / 2\right]} L
$$

where $D_{1}(\mathrm{~m})$ and $D_{2}(\mathrm{~m})$ are the diameters in both upper and lower extremes of the pole and $L$ is the pole length (m).

2.3. Physical Properties (Wood Density). The material for physical and mechanical assays was obtained from heartwood in the bole zone, $0.3 \mathrm{~m}$ to $1.3 \mathrm{~m}$ above the tree base, according to Panshin and Zeeuw [31]. The basic densities of the ten species were measured by testing 30 wood specimens 
TABLE 1: Outstanding characteristics of the 10 woody plant species selected for study.

\begin{tabular}{|c|c|c|c|}
\hline Family & Species & Characteristics and life form & Uses \\
\hline $\begin{array}{l}\text { Leguminosae } \\
\text { (Mimosoideae) }\end{array}$ & $\begin{array}{l}\text { Acacia farnesiana (L.) } \\
\text { Willd }\end{array}$ & $\begin{array}{l}\text { Shrubs/trees 3-6 (10) m, 10-20 cm diameter, early } \\
\text { invader of pastures, good natural resistance of wood, } \\
\text { distributed throughout semiarid zones of Mexico, } \\
\text { southern USA, and Central and South America }\end{array}$ & $\begin{array}{l}\text { Firewood, wood, charcoal, posts, } \\
\text { construction, and honey } \\
\text { (Flowers) }\end{array}$ \\
\hline $\begin{array}{l}\text { Leguminosae } \\
\text { (Fabaceae) }\end{array}$ & $\begin{array}{l}\text { Acacia schaffneri var. } \\
\text { schaffneri (S. Watson) } \\
\text { F. J. Herm. }\end{array}$ & $\begin{array}{l}\text { Tree } 4-6 \mathrm{~m} \text { height, } 20-25 \mathrm{~cm} \text { diameter, covered with } \\
\text { velvety or stiff hair. Distribution: northern Mexico and } \\
\text { south Texas, USA }\end{array}$ & $\begin{array}{l}\text { Firewood, wood hard and heavy, } \\
\text { charcoal, construction, forage } \\
\text { (pods) }\end{array}$ \\
\hline Sapotaceae & $\begin{array}{l}\text { Bumelia celastrina } \\
\text { Kunth }\end{array}$ & $\begin{array}{l}\text { Small, thorny tree } 8-10(12 \mathrm{~m}) \text { height, } 30-40 \mathrm{~cm} \\
\text { diameter, tall shrub of the Rio Grande Plains, } \\
\text { hardwood with a very good natural resistance }\end{array}$ & $\begin{array}{l}\text { Wood, firewood, post, and shade } \\
\text { for animal }\end{array}$ \\
\hline Rhamnaceae & $\begin{array}{l}\text { Condalia hookeri M. } \\
\text { C. Johnst. }\end{array}$ & $\begin{array}{l}\text { Small spiny tree } 6-9 \mathrm{~m} \text { height, } 30-40 \mathrm{~cm} \text { diameter } \\
\text { that forms thickets and chaparral. Distribution: } \\
\text { northeastern, northwestern and Baja California, } \\
\text { Mexico }\end{array}$ & $\begin{array}{l}\text { Wood, firewood, forage, and } \\
\text { food }\end{array}$ \\
\hline $\begin{array}{l}\text { Leguminosae } \\
\text { (Caesalpiniaceae) }\end{array}$ & $\begin{array}{l}\text { Cercidium macrum } \\
\text { Johnst. }\end{array}$ & $\begin{array}{l}\text { Small tree } 3-6 \mathrm{~m} \text { tall, } 15-20 \mathrm{~cm} \text { diameters, bark } \\
\text { smooth, green, branches slightly zigzagging and armed } \\
\text { with solitary spines }\end{array}$ & Firewood, post, forage (goat) \\
\hline Leguminosae & $\begin{array}{l}\text { Ebenopsis ebano } \\
\text { (Berl.) Barneby and } \\
\text { Grimes }\end{array}$ & $\begin{array}{l}\text { Tree 3-10 }(15) \mathrm{m}, 50(120) \mathrm{cm} \text { diameter, hardwood, } \\
\text { dark with a very good natural resistance. Distributed in } \\
\text { northern Mexico, southwestern Texas, in the lowland }\end{array}$ & $\begin{array}{l}\text { Firewood, charcoal, wood } \\
\text { (furniture), shade for animal } \\
\text { protection, and food (fruit and } \\
\text { pods) }\end{array}$ \\
\hline Myrtaceae & $\begin{array}{l}\text { Eucalyptus } \\
\text { camaldulensis Dehnh. } \\
\text { (river red gum) }\end{array}$ & $\begin{array}{l}\text { Tall fast growing tree } 15 \text { to } 45 \mathrm{~m} \text {; basal diameter over } \\
2 \mathrm{~m} \text { with flaky or smooth bark ranging in color from } \\
\text { white and grey to red-brown which is shed in long } \\
\text { ribbons. The tree has a large, dense crown. The base of } \\
\text { the trunk can be covered with rough, reddish-brown } \\
\text { bark. The tree grows straight under favorable } \\
\text { conditions but can develop twisted branches in drier } \\
\text { conditions }\end{array}$ & $\begin{array}{l}\text { Stumps, fence posts and wood } \\
\text { sleepers, craft furniture, timber } \\
\text { for wood, firewood, charcoal, } \\
\text { paper pulp, ornamental, and } \\
\text { medicinal }\end{array}$ \\
\hline Rutaceae & $\begin{array}{l}\text { Helietta parvifolia } \\
\text { (Gray) Benth. }\end{array}$ & $\begin{array}{l}\text { Large shrub or small tree } 2-10(12) \mathrm{m} \text {, early invader in } \\
\text { calcareous soils, deep root system with very high } \\
\text { natural resistance of wood, is distributed in } \\
\text { northeastern Mexico and Texas, USA }\end{array}$ & $\begin{array}{l}\text { Poles, shelves, wood, charcoal, } \\
\text { medicinal }\end{array}$ \\
\hline Leguminosae & $\begin{array}{l}\text { Leucaena leucocephala } \\
\text { (Lam.) de Wit. } \\
\text { Naturalized species to } \\
\text { the region }\end{array}$ & $\begin{array}{l}\text { Native from Yucatan Peninsula, } 5-8(20) \mathrm{m} \text { thick, half } \\
\text { dense wood, average natural resistance. It is distributed } \\
\text { in southern Mexico and Central America }\end{array}$ & $\begin{array}{l}\text { Firewood, charcoal, shelves, rural } \\
\text { construction, green manure, } \\
\text { windbreak, nitrogen-fixing }\end{array}$ \\
\hline Leguminosae & $\begin{array}{l}\text { Prosopis laevigata } \\
\text { (Humb. et Bonpl.) M. } \\
\text { C. Johnst. }\end{array}$ & $\begin{array}{l}\text { Tree } 5-10(15) \mathrm{m}, 50(80) \mathrm{cm} \text { diameter, dense wood } \\
\text { with a high natural resistance. It is distributed in } \\
\text { northeastern Mexico, especially in the mountain scrub, } \\
\text { and southern Texas }\end{array}$ & $\begin{array}{l}\text { Poles, shelves, wood, charcoal, } \\
\text { construction, and shade for } \\
\text { edible pastures }\end{array}$ \\
\hline
\end{tabular}

Sources: [25-30].

per species with dimensions $10 \times 20 \times 20 \mathrm{~mm}$, corresponding to longitudinal $\times$ radial $\times$ tangential directions, respectively. Volume was measured on green condition of the specimens (specimens obtained immediately after felling the trees). Dry weight was obtained after drying the specimens at $103 \pm 3^{\circ} \mathrm{C}$ until constant weight was reached. The basic density was calculated by the following formula:

$$
\rho^{B}=\frac{m_{\text {dry }}}{v_{g}},
$$

where $\rho^{B}=$ Basic density $\left(\mathrm{g} \mathrm{cm}^{-3}\right), m_{\text {dry }}=$ mass $(\mathrm{g})$ on oven dry condition $\left(103^{\circ} \mathrm{C}\right)$ and $v_{g}=$ green volume $\left(\mathrm{cm}^{3}\right)$.

2.4. Statistical Analysis. Growth parameters and volume measurements were converted to amounts per each woody tree. The mean values and standard errors were calculated for each species. Regression models were applied to determine the $R^{2}$ (coefficient of determination) between crown area and the increment parameters (height and basal diameter) [32]. Contrast tests (Duncan's multiple-range test-DMRT) were applied to compare the obtained mean values [33] with 
TABLE 2: Duncan's multiple-range test (DMRT) for height, basal diameter (BD), and diameter at breast height (DBH) parameters. Coefficient of determination $\left(R^{2}\right)$ was calculated between crown area and height and between crown area and basal diameter.

\begin{tabular}{|c|c|c|c|c|c|}
\hline \multirow{2}{*}{ Species } & \multicolumn{3}{|c|}{ Average dimension (m) } & \multicolumn{2}{|c|}{$R^{2}$ between crown and } \\
\hline & Height & $\mathrm{BD}$ & $\mathrm{DBH}$ & Height & $\mathrm{BD}$ \\
\hline Acacia farnesiana & $4.8^{\mathrm{G} *}$ & $0.41^{\mathrm{CD}}$ & $0.36^{\mathrm{C}}$ & 0.61 & 0.75 \\
\hline Acacia schaffneri & $4.1^{\mathrm{H}}$ & $0.30^{\mathrm{G}}$ & $0.27^{\mathrm{F}}$ & 0.58 & 0.54 \\
\hline Bumelia celastrina & $5.2^{\mathrm{F}}$ & $0.33^{\mathrm{EF}}$ & $0.31^{\mathrm{E}}$ & 0.72 & 0.64 \\
\hline Cercidium macrum & $6.8^{\mathrm{D}}$ & $0.36^{\mathrm{E}}$ & $0.30^{\mathrm{E}}$ & 0.81 & 0.85 \\
\hline Condalia hookeri & $6.1^{\mathrm{E}}$ & $0.42^{\mathrm{CD}}$ & $0.37^{\mathrm{CD}}$ & 0.52 & 0.57 \\
\hline Ebenopsis ebano & $7.4^{\mathrm{C}}$ & $0.44^{\mathrm{C}}$ & $0.39^{\mathrm{C}}$ & 0.73 & 0.78 \\
\hline Eucalyptus camaldulensis & $15.6^{\mathrm{A}}$ & $0.58^{\mathrm{A}}$ & $0.52^{\mathrm{A}}$ & 0.70 & 0.64 \\
\hline Helietta parvifolia & $5.0^{\mathrm{F}}$ & $0.26^{\mathrm{GH}}$ & $0.23^{\mathrm{G}}$ & 0.64 & 0.57 \\
\hline Leucaena leucocephala & $6.5^{\mathrm{D}}$ & $0.32^{\mathrm{EF}}$ & $0.25^{\mathrm{F}}$ & 0.62 & 0.51 \\
\hline Prosopis laevigata & $8.7^{\mathrm{B}}$ & $0.51^{\mathrm{AB}}$ & $0.48^{\mathrm{B}}$ & 0.71 & 0.63 \\
\hline
\end{tabular}

${ }^{*}$ Values in columns with different superscripts differ $(P<0.05)$.

the statistical package SPSS (v. 15.0). Least significant differences were calculated at 5\% probability level (LSD 0.05) according to Zar [32].

\section{Results and Discussion}

3.1. Height, Diameter, and Crown Development. The height and diameter parameters are proper indicators of the site conditions (soil and climate) although they are also dependent on factors such as interspecific competition, standard density, and climatic conditions. The latter factor seems to determine the growth and development of the evaluated species in northeastern Mexico. In the present investigation the introduced woody species (in monoculture systems) showed an adequate height, diameter at breast height, and basal diameter increments in comparison to the native species in northeastern Mexico (Table 2).

Eucalyptus camaldulensis and Leucaena leucocephala, naturalized species with an average height of 15.6 and $6.5 \mathrm{~m}$, respectively, and $0.52 \mathrm{~m}$ and $0.25 \mathrm{~m}$ of BD increment, showed both a remarkable and fastest growth rate in addition to a particularly high drought resistance even though their individuals were more sensitive to low temperatures during winter and at the beginning of the growing season. However, their sensitivity to low temperatures does not limit their use as a forest tree while their rapid growth makes them ideal for forestry and agroforestry purposes.

Prosopis laevigata ( $8.7 \mathrm{~m}$ in height and $0.51 \mathrm{~m}$ in $\mathrm{BD})$, Ebenopsis ebano (7.4 $\mathrm{m}$ in height, $0.44 \mathrm{~m}$ in $\mathrm{BD}$ ), Cercidium macrum $(6.8 \mathrm{~m}$ in height and $0.36 \mathrm{~m}$ in $\mathrm{BD})$, and Condalia hookeri $(6.1 \mathrm{~m}$ in height and $0.42 \mathrm{~m}$ in $\mathrm{BD})$ showed high growth potential, although to a lesser extent than Eucalyptus camaldulensis and Leucaena leucocephala and in general terms did not suffer significant reductions in height due to environmental causes. Acacia farnesiana (4.8 m), Acacia schaffneri $(4.1 \mathrm{~m})$, Bumelia celastrina $(5.2 \mathrm{~m})$, and Helietta parvifolia $(5.0 \mathrm{~m})$ constitute a special group of species and showed an intermediate growth rate between these two groups.

Since most of the species employed in this study developed a broad disperse canopy, the stand density varied among species as the trees matured. The high plant density corresponding to the thornscrub of northeastern Mexico (over 2,500 plants $\mathrm{ha}^{-1}$ ) and the surface available (between trees) in the natural vegetation notably influenced the growth in height and diameter of all species.

Under normal conditions, wood and firewood volume production is a function of height and crown size in arborescent dicotyledonous species in which the lateral branches grow more quickly than the central apex. This growth habit gives rise to a broad disperse canopy, especially in poor or dry sites [34].

Cercidium macrum $\left(R^{2}=0.85\right)$, Ebenopsis ebano $\left(R^{2}=\right.$ $0.78)$, Acacia farnesiana $\left(R^{2}=0.75\right)$, and Prosopis laevigata $\left(R^{2}=0.71\right)$ produced a broad crown which promote their ability to develop a large basal diameter. Data suggest that these species are more capable to develop properly in cleared sites along their natural distribution areas than other native and introduced woody plants. This is an important consideration for forestry and silvicultural management in the Tamaulipan thornscrub. Aggressive crown expansion of native species may inhibit the growth of slow-growing valuable wood-producing trees in mixed stands if species have heterogeneous growth rates.

The analysis of the development and environmental responses of each tree species using commonly accepted criteria, such as survivorship and growth in height, diameter, and projected foliage cover, suggest that each species has unique aspects of growth potential. The relationship between variables helps to highlight these characteristics. It has been observed that the growth rate of the ten species is very different in semiarid zones of northeastern Mexico. Heiseke and Foroughbakhch [22] obtained a mean annual diameter increment (at breast height) of $0.2-0.4 \mathrm{~cm} \mathrm{year}^{-1}$ and a height increment of 13-24 cm year ${ }^{-1}$ for 296 woody native species. The data are the means for approximately 30 species, including most of native species grown in natural vegetation.

3.2. Wood Volume Determination. The high biomass production of most species is important not only to the production of the shoots as pasture for the animals but also as an energetic source in production of posts, firewood, and other 
TABLE 3: Comparison between wood volume production $\left(\mathrm{m}^{3}\right.$ tree $\left.\mathrm{e}^{-1}\right)$ of ten wood species in the natural vegetation and monoculture systems in a semiarid region of Mexico.

\begin{tabular}{|c|c|c|c|c|}
\hline \multirow{2}{*}{ Species } & \multicolumn{2}{|c|}{ Firewood volume per tree in } & \multicolumn{2}{|c|}{ Monoculture systems } \\
\hline & Natural vegetation & Monoculture systems & Firewood volume ha ${ }^{-1}$ & Density ha ${ }^{-1}$ \\
\hline Acacia farnesiana & $0.011585^{\mathrm{D} *}$ & $0.014715^{\mathrm{F}}$ & $29.43^{\mathrm{EF}}$ & 2300 \\
\hline Acacia schaffneri & $0.010342^{\mathrm{E}}$ & $0.012155^{\mathrm{G}}$ & $21.88^{\mathrm{H}}$ & 2000 \\
\hline Bumelia celastrina & $0.011103^{\mathrm{D}}$ & $0.010640^{\mathrm{H}}$ & $21.28^{\mathrm{H}}$ & 1850 \\
\hline Cercidium macrum & $0.012231^{\mathrm{D}}$ & $0.011527^{\mathrm{G}}$ & $25.36^{\mathrm{G}}$ & 2000 \\
\hline Condalia hookeri & $0.015245^{\mathrm{B}}$ & $0.018091^{\mathrm{DE}}$ & $31.66^{\mathrm{E}}$ & 1850 \\
\hline Ebenopsis ebano & $0.020349^{\mathrm{A}}$ & $0.026618^{\mathrm{B}}$ & $43.92^{\mathrm{C}}$ & 1850 \\
\hline Eucalyptus camaldulensis & - & $0.083642^{\mathrm{A}}$ & $58.54^{\mathrm{A}}$ & 700 \\
\hline Helietta parvifolia & $0.014635^{\mathrm{BC}}$ & $0.019160^{\mathrm{D}}$ & $28.74^{\mathrm{EF}}$ & 1850 \\
\hline Leucaena leucocephala & - & $0.024367^{\mathrm{C}}$ & $48.73^{\text {B }}$ & 2000 \\
\hline Prosopis laevigata & $0.020788^{\mathrm{A}}$ & $0.027553^{\mathrm{B}}$ & $41.33^{\mathrm{CD}}$ & 1750 \\
\hline
\end{tabular}

* Values in columns with different superscripts differ $(P<0.05)$.

products. The results of the harvested firewood yield volume of 10 native and naturalized species (Table 3 ) in natural and monoculture vegetation of northeastern Mexico indicated a higher production in forest biomass. Data on volume indicated that Eucalyptus camaldulensis $\left(0.083642 \mathrm{~m}^{3}\right.$ plant $^{-1}$ and $\left.58.54 \mathrm{~m}^{3} \mathrm{ha}^{-1}\right)$, Leucaena leucocephala $\left(0.024367 \mathrm{~m}^{3}\right.$ plant $^{-1}$ and $\left.48.73 \mathrm{~m}^{3} \mathrm{ha}^{-1}\right)$, Prosopis laevigata $\left(0.020788 \mathrm{~m}^{3}\right)$, and Ebenopsis ebano $\left(0.020349 \mathrm{~m}^{3}\right)$ demonstrated a high production per tree in natural vegetation, with an average population density of woody tree species between 700 (introduced species in plantation) and 1800 plant $\mathrm{ha}^{-1}$ (native species). Results indicate that the biomass production is high for most of the evaluated species compared to the native species as Acacia schaffneri $\left(0.010342 \mathrm{~m}^{3}\right)$, Bumelia celastrina $\left(0.011103 \mathrm{~m}^{3}\right)$, Acacia farnesiana $\left(0.011585 \mathrm{~m}^{3}\right)$, and Cercidium macrum $\left(0.012231 \mathrm{~m}^{3}\right.$ plant $^{-1}$ ) thereby indicating a quick growth of these species both in height and diameter.

In general terms, the production of firewood and timber by native plant species growing in nature is well below the values obtained for the same species under plantation in monoculture systems. This difference is attributed to the high density of plants (more than 2,500 plants ha ${ }^{-1}$ ), the interspecific competition, and the presence of species such as Helietta parvifolia with allelopathic characteristics. The fuelwood situation in developing countries can be improved by planting more trees and improving the management practices of the existing forest resources [35]. In the arid and semiarid zones of northeastern Mexico, firewood planting can use species with short boles, crooked trunk, or wood that warps or splits as it dries. These features are not as detrimental to fuelwood use as to timber production nor is stem size. In simple cook stoves, for example, branches as small as 4 or $5 \mathrm{~cm}$ in diameter may be ideal. Thus a shrub may prove satisfactory for village fuelwood silviculture if it grows fast and produces a dense wood that burns with intense heat [36].

Indiscriminate wood and firewood collection is currently one of the main causes of reduction of native vegetation in northeastern Mexico. Intensive plantations with native woody species on accessible sites can help to relieve this pressure on natural forests by supplying a large share of the needed firewood more conveniently.

3.3. Physical Properties of Woody Plants. Density defined as the mass per unit volume is an accurate indicator regarding wood resistance of wood and the amount of cell wall substance. Thus, there should be a strong correlation between the basic density and the mechanical properties [31, 37, 38]. The basic density of the ten species from thornscrub is presented in Table 4.

Basic density from the tree species was classified according to the 10-type classification system developed by Panshin and Zeeuw [31]. Table 4 shows the five classes obtained. Leucaena leucocephala and Eucalyptus camaldulensis (6th class) with $0.42-0.50 \mathrm{~g} \mathrm{~cm}^{-3}$ (average basic density $=0.47 \pm$ $0.05 \mathrm{~g} \mathrm{~cm}^{-3}$ ). Cercidium macrum (7th class) with $0.55 \pm$ $0.01 \mathrm{~g} \mathrm{~cm}^{-3}$, the only species in this group. A density value of 0.54 from plantations for $L$. leucocephala was reported [39]. Two species on class 8 th $\left(0.60-0.72 \mathrm{~g} \mathrm{~cm}^{-3}\right)$ were found: Bumelia celastrina $\left(0.64 \pm 0.03 \mathrm{~g} \mathrm{~cm}^{-3}\right)$ and Acacia farnesiana $\left(0.65 \pm 0.02 \mathrm{~g} \mathrm{~cm}^{-3}\right)$. On class 9th were Prosopis laevigata $\left(0.75 \pm 0.04 \mathrm{~g} \mathrm{~cm}^{-3}\right)$, Acacia schaffneri $\left(0.79 \pm 0.05 \mathrm{~g} \mathrm{~cm}^{-3}\right)$, and Helietta parvifolia $\left(0.82 \pm 0.03 \mathrm{~g} \mathrm{~cm}^{-3}\right)$. Class 10 th stands for species with a density higher than $0.86 \mathrm{~g} \mathrm{~cm}^{-3}$; the only two species on this class were Ebenopsis ebano (0.86 \pm $\left.0.08 \mathrm{~g} \mathrm{~cm}^{-3}\right)$ and Condalia hookeri $\left(0.93 \mathrm{~g} \mathrm{~cm}^{-3}\right)$. According to the basic densities detected on this research, the management of thornscrub species should be focused in promoting their industrial use, especially those from classes from 7 to 9 . However, the least dense species as Leucaena leucocephala and E. camaldulensis could be integrated on multipurpose plantations for biomass production.

Mechanical properties are used to describe the wood strength and the ability of the wood to resist applied or external forces [40]. Elasticity is defined as the property which enables a loaded material to recover its original form after the load is removed; if the load is greater than a certain value, 
TABLE 4: Physical properties (density $\mathrm{g} \mathrm{cm}^{-3}$ ) of ten timber species of northeastern Mexico.

\begin{tabular}{|c|c|c|c|c|c|}
\hline Species & Min. & Average & Max. & STD & $\mathrm{CV}$ \\
\hline Acacia farnesiana & 0.61 & 0.65 & 0.69 & 0.02 & 3.13 \\
\hline Acacia schaffneri & 0.65 & 0.79 & 0.88 & 0.06 & 7.50 \\
\hline Bumelia celastrina & 0.50 & 0.64 & 0.70 & 0.04 & 5.98 \\
\hline Cercidium macrum & 0.53 & 0.55 & 0.58 & 0.02 & 2.82 \\
\hline Condalia hookeri & 0.76 & 0.93 & 1.06 & 0.07 & 8.01 \\
\hline Ebenopsis ebano & 0.70 & 0.87 & 1.00 & 0.08 & 9.60 \\
\hline Eucalyptus camaldulensis & 0.49 & 0.55 & 0.61 & 0.09 & 10.45 \\
\hline Helietta parvifolia & 0.77 & 0.83 & 0.89 & 0.04 & 4.44 \\
\hline Leucaena leucocephala & 0.41 & 0.48 & 0.57 & 0.06 & 11.51 \\
\hline Prosopis laevigata & 0.60 & 0.76 & 0.82 & 0.04 & 5.48 \\
\hline
\end{tabular}

the material will display a plastic deformity or even failure. The elasticity and density properties are fundamental in determining the quality of wood [41].

\section{Conclusions}

A major need for the semiarid forest of northeastern Mexico is the rehabilitation of those marginal lands which have been highly degraded, compacted, and presently eroded by inadequate forestry and agroforestry activities. On less productive soils, forestry with a pastoral component should be established, especially in places with native vegetation, which is under severe pressure due to wood exploitation and overgrazing. In this sense, a structural analysis on woody trees in terms of growth and forest productivity (volume and density of wood) of ten species of ecological importance to the rural population and regional industry in northeastern Mexico was made.

Growth rates and wood volume of Eucalyptus camaldulensis and Leucaena leucocephala as exotics species were clearly superior to all other species and showed the highest yield under the soil and climate of thornscrubs of northeastern Mexico; thus, these species have the potentiality to become important for fuelwood and forestry activity for the region. Prosopis laevigata, Ebenopsis ebano, and Condalia hookeri showed characteristics of woody species and a strong capacity for precocious canopy expansion. Helietta parvifolia and in a lesser extend Bumelia celastrina share similar characteristics.

Acacia farnesiana and Acacia schaffneri are exploited for multiple purposes and should be considered for future planting in forestry and silvicultural systems. Helietta parvifolia and Condalia hookeri are considered important fuelwood sources, but detailed studies are required because these species are an important timber resource in the Tamaulipan thornscrub providing the rural community with hard and durable posts for fences and construction. The rest of the species showed good growth and a high forest potential playing an important role in the diversification of silvicultural activities and management programs in native areas.

Results on the physical and mechanical properties of these ten species from thornscrub show noteworthy values on several woody species, for example, basic density for Condalia hookeri, Ebenopsis ebano, and Helietta parvifolia, high modulus elasticity, and rupture for Acacia schaffneri, Ebenopsis ebano, and Helietta parvifolia. Grouping species on density classes allow us to find species with similar characteristics that could be used together. This grouping may apply for several tree species growing in the thornscrub with similar density values, for example, between species on classes II and III, to be used for similar purposes.

There is obviously a great interest for a larger use of leguminous trees for wood volume, firewood, and shade. Among the main reasons is the need for reforestation with trees that restore soil fertility (leguminous species) while binding the soil with their roots and allowing better water infiltration. The general methodology applied in this research gave positive results that could be used to develop strategy actions in forest programs (reforestation and rehabilitation of degraded ecosystems) with proper management plans for timber species in order to preserve plant communities of semiarid areas of Mexico.

\section{References}

[1] SEMARNAT. Producción forestal maderable y no maderable. Secretaria de Medio Ambiente y Recursos Naturales, 2007, http://app1.semarnat.gob.mx/dgeia/indicadores04/07_ forestales/ficha_7_2.shtml.

[2] T. J. B. Boyle and B. Bonontawee, "Measuring and monitoring biodiversity in tropical and temperate forests," in Center for International Forestry Research, Bogor, Indonesia, 1995.

[3] J. C. Tewari, P. J. C. Harris, L. N. Harsh, K. Cadoret, and N. M. Pasiecznik, "Managing Prosopis juliflora (Vilayati babul)," A Technical Manual, Central Arid Zone Research Institute and HDRA, 2000.

[4] N. Reid, J. Marroquín, and P. Beyer-Münzel, "Utilization of shrubs and trees for browse, fuelwood and timber in the Tamaulipan thornscrub, northeastern Mexico," Forest Ecology and Management, vol. 36, no. 1, pp. 61-79, 1990.

[5] P. F. Ffolliott and J. L. Thames, Handbook on Taxonomy of Prosopis in Mexico, Peru and Chile, Rome, Italy, 1983.

[6] F. C. Rodríguez and A. L. J. Maldonado, "Overview of past, current and potential uses of mesquite in Mexico," in Prosopis; Semiarid Fuel Wood and Forage Tree Building Consensus for 
the Disemfranchised. Center from Semi-arid Forest Resources, R. Felker and J. Moss, Eds., pp. 6.41-6.52, Texas A\&M University, Washington, DC, USA, 1996.

[7] V. S. Meraz, V. J. Orozco, C. J. A. Lechuga, S. F. Cruz, and C. J. Veron, Mesquite, árbol de gran utilidad. Ciencias 51, 1998.

[8] E. M. González, E. J. Treviño, and O. A. Aguirre, "Fisonomía y composición de la vegetación secundaria en un área de Matorral del Noreste de México," Phytologia, vol. 84, no. 4, pp. 257-269, 1997.

[9] H. G. Rodríguez, I. C. Silva, M. V. G. Meza, and W. R. Jordan, "Seasonal plant water relationships in Acacia berlandieri," Arid Soil Research and Rehabilitation, vol. 14, no. 4, pp. 343-357, 2000.

[10] A. Carrillo, I. Mayer, G. Koch, and F. Hapla, "Wood anatomical characteristics and chemical composition of Prosopis laevigata grown in the northeast of Mexico," IAWA Journal, vol. 29, no. 1, pp. 25-34, 2008.

[11] A. Carrillo, M. Garza, M. J. Nañez, F. Garza, R. Foroughbakhch, and S. Sandoval, "Physical and mechanical wood properties of 14 timber species from Northeast Mexico," Annals of Forest Science, vol. 68, no. 1, pp. 675-679, 2011.

[12] R. Foroughbakhch, M. A. Alvarado-Vázquez, A. NúñezGonzález, J. Hernández-Piñero, and A. Rocha-Estrada, "Structural analysis and performance of Helietta parvifolia (gray) benth. In Southeastern Nuevo Leon, Mexico," Interciencia, vol. 28, no. 11, pp. 651-655, 2003.

[13] J. S. Spears, "Wood as an energy source: the situation in the developing world," in Proceedings of the 103rd Annual Meeting of the American Forest Association, Hot Springs, Arkansas, Ark, USA, 1978.

[14] E. García, Modificaciones al Sistema de Clasificación Climática de Köppen, 5th, Instituto de Geografía, Universidad Nacional Autónoma de México, 5th edition, 2004.

[15] J. Návar, E. Méndez, A. Nájera, J. Graciano, V. Dale, and B. Parresol, "Biomass equations for shrub species of Tamaulipan thornscrub of North-eastern Mexico," Journal of Arid Environments, vol. 59, no. 4, pp. 657-674, 2004.

[16] J. Návar, F. Charles, and E. Jurado, "Spatial variations of interception loss components by Tamaulipan thornscrub in northeastern Mexico," Forest Ecology and Management, vol. 124, no. 2-3, pp. 231-239, 1999.

[17] J. Navar and R. B. Bryan, "Fitting the analytical model of rainfall interception of Gash to individual shrubs of semi-arid vegetation in northeastern Mexico," Agricultural and Forest Meteorology, vol. 68, no. 3-4, pp. 133-143, 1994.

[18] FAO-UNESCO, FAO-UNESCO Soil Map of the World, vol. 1, UNESCO, Paris, France, 1974.

[19] M. G. Manzano, Procesos de desertificación asociados a sobrepastoreo por caprinos en el matorral espinoso de Linares, M.S. thesis, Facultad de Ciencias Forestales, UANL, Mexico, Nuevo León, Mexico, 1997.

[20] A. G. De Soyza, W. G. Whitford, E. Martinez-Meza, and J. W. Van Zee, "Variation in creosotebush (Larrea tridentata) canopy morphology in relation to habitat, soil fertility and associated annual plant communities," American Midland Naturalist, vol. 137, no. 1, pp. 13-26, 1997.

[21] F. Wolf and F. Perales, "Durabilidad natural de la madera de algunas especies del matorral del noreste de México," Reporte Científico No. 3, Facultad de Silvicultura y Manejo de Recursos Renovables, 1985.

[22] D. Heiseke and R. Foroughbakhch, "El matorral como recurso forestal: evaluación de dos tipos de matorral en la región de Linares," Reporte Científico No. 1: 1-28, UANL, Nuevo León, Mexico, 1985.
[23] D. Mueller-Dombois and H. Ellenberg, Aims and Methods of Vegetation Ecology, John Wiley \& Sons, New York, NY, USA, 1974.

[24] G. Meskimen and E. C. Franklin, "Spacing Eucalyptus grandis in Southern Florida," Southern Journal of Applied Forestry, vol. 1, no. 1, pp. 3-5, 1979.

[25] J. L. Brewbaker, "Species in the genus Leucaena," Leucaena Research Reports, vol. 7, no. 2, pp. 6-20, 1987.

[26] CATIE, Centro Agronómico Tropical de Investigación y Enseñanza, Silvicultura de especies Promisorias Para producción de Leña en América Central, CATIE, Turrialba, Costa Rica, 1986.

[27] F. Hormazabal, Especies Forestales Exóticas de Interés Económico Para Chile, Instituto Forestal, Santiago, Chile, 1986.

[28] A. Niembro-Rocas, Arboles y Arbustos Útiles de México, Limusa, Balderas, Mexico, 1990.

[29] C. E. Hughes, Leucaena Genetic Resources. The OFI Leucaena Seed Collections and a Synopsis of Species Characteristics, Departament of Plant Sciences, Oxford Forestry Institute, University of Oxford, Oxford, UK, 1993.

[30] C.G. Velazco-Macías, G. Alanis-Flores, M. Alvarado-Vázquez, L. Ramírez-Freire, R., and R. Foroughbakhch-Pournavab, "Endemic flora from Nuevo León, Mexico and adjacent states," Journal of the Botanical Research Institute of Texas, vol. 5, pp. 275-298, 2011.

[31] A. J. Panshin and C. D. Zeeuw, Textbook of Wood Technology, McGraw-Hill, New York, NY, USA, 4th edition, 1980.

[32] J. H. Zar, Biostatistical Analysis, Prentice-Hall, Upper Saddle River, NJ, USA, 5th edition, 2010.

[33] K. Hinkelmann and O. Kempthorne, Design and Analysis of Experiments. Introduction to Experimental Design, vol. 1, John Wiley \& Sons, New York, NY, USA, 1994.

[34] J. Burley, "Selection of species for fuelwood plantations," in Proceedings of the 8th World Forestry Congress, Jakarta, Indonesia, 1978 .

[35] J. A. Semana, P. V. Bawagan, F. R. Sirimban, and V. B. Mendoza, A Feasibility Study of the Utilization of Man-Made Forests for Generating Electricity, Forest Product Research and Industries Development Commission, National Science Development Board, Laguna, Philippines, 1977.

[36] R. Dávalos and G. M. Bárcenas, "Clasificación de las propiedades mecánicas de las maderas mexicanas en condición 'seca," Madera y Bosques, vol. 5, no. 1, pp. 61-69, 1999.

[37] F. F. P. Kollmann and W. A. Cote, Principles of Wood Science and Technology. I. Solid Wood, Springer, New York, NY, USA, 1968.

[38] Forest Products Laboratory, Wood Handbook-Wood as an Engineering Material, Department of Agriculture, Forest Service, Forest Products Laboratory, Madison, Wis, USA, 1999.

[39] P. R. Gillah and R. C. Ishengoma, "Kraft pulping of Leucaena leucocephala grown in Morogoro, Tanzania," Holz als Roh- und Werkstoff, vol. 51, no. 5, pp. 353-356, 1993.

[40] S. J. Record, "The mechanical properties of the wood. Including a discussion of the factors affecting the mechanical properties, and methods of timber testing," 2004, http://www2 .cddc.vt.edu/gutenberg/1/2/2/9/12299/12299-h/12299-h.htm \#PREFACE.

[41] J. Ilic, "Dynamic MOE of 55 species using small wood beams," Holz als Roh-und Werkstoff, vol. 61, no. 3, pp. 167-172, 2003. 

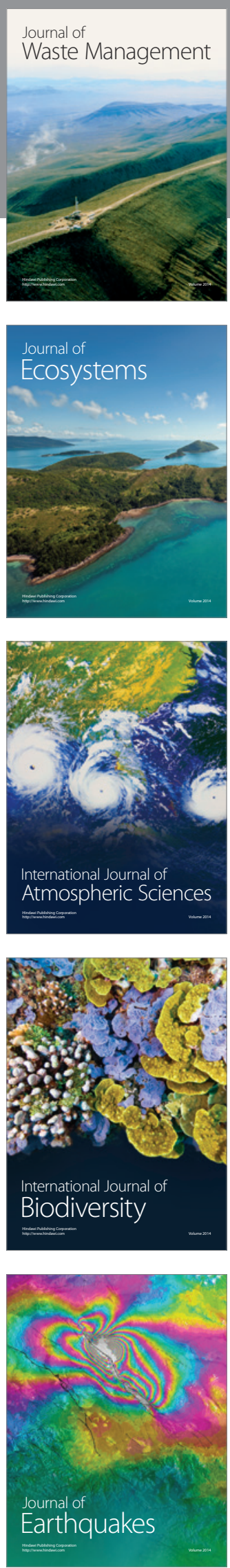
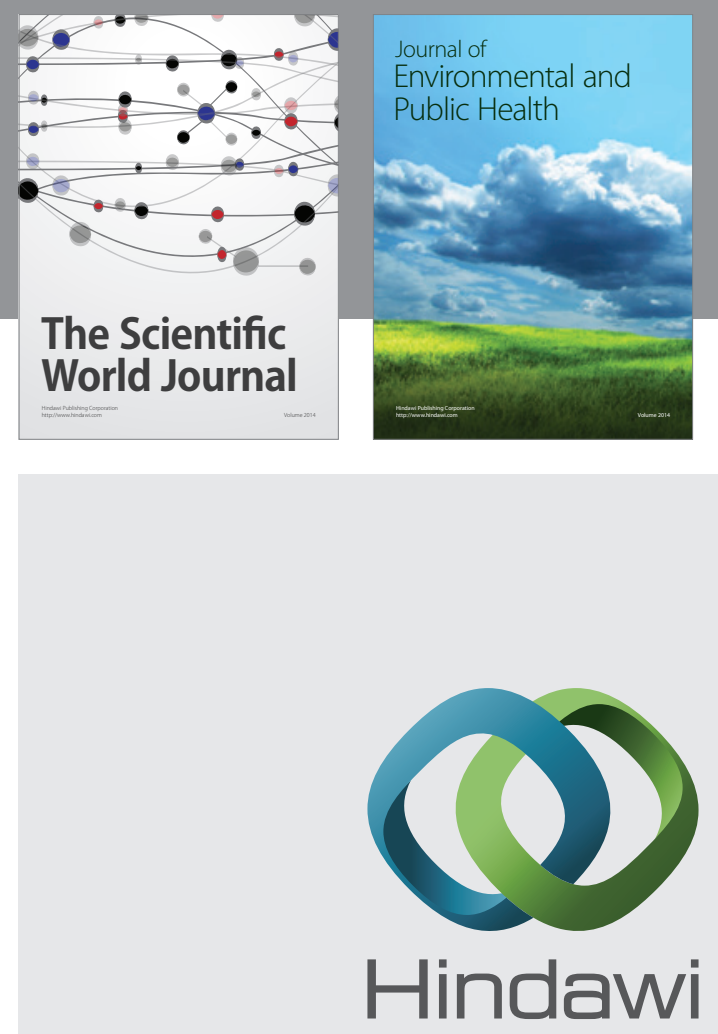

Submit your manuscripts at

http://www.hindawi.com
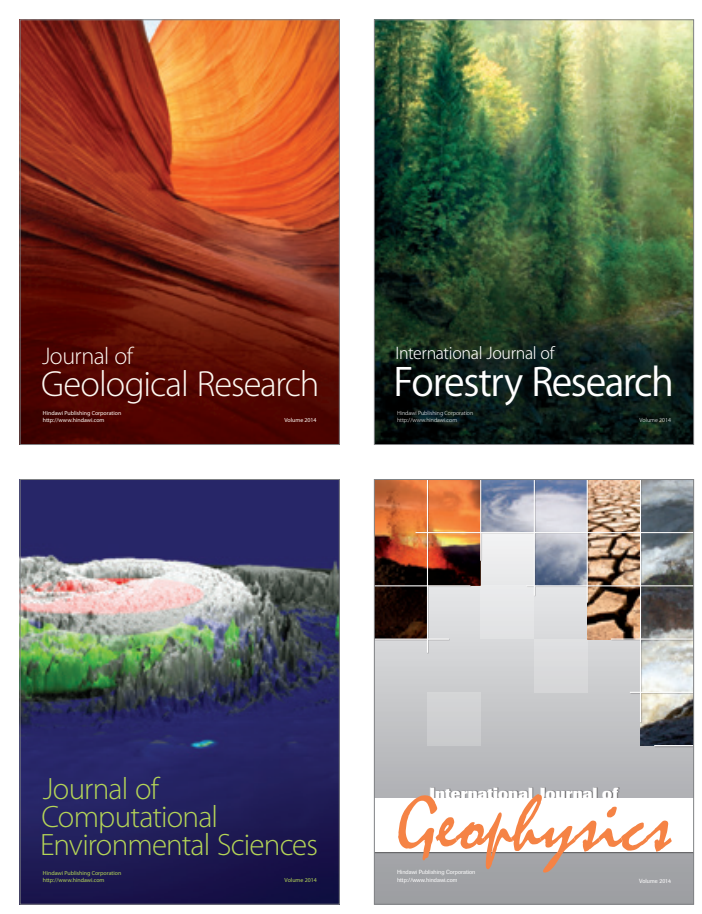
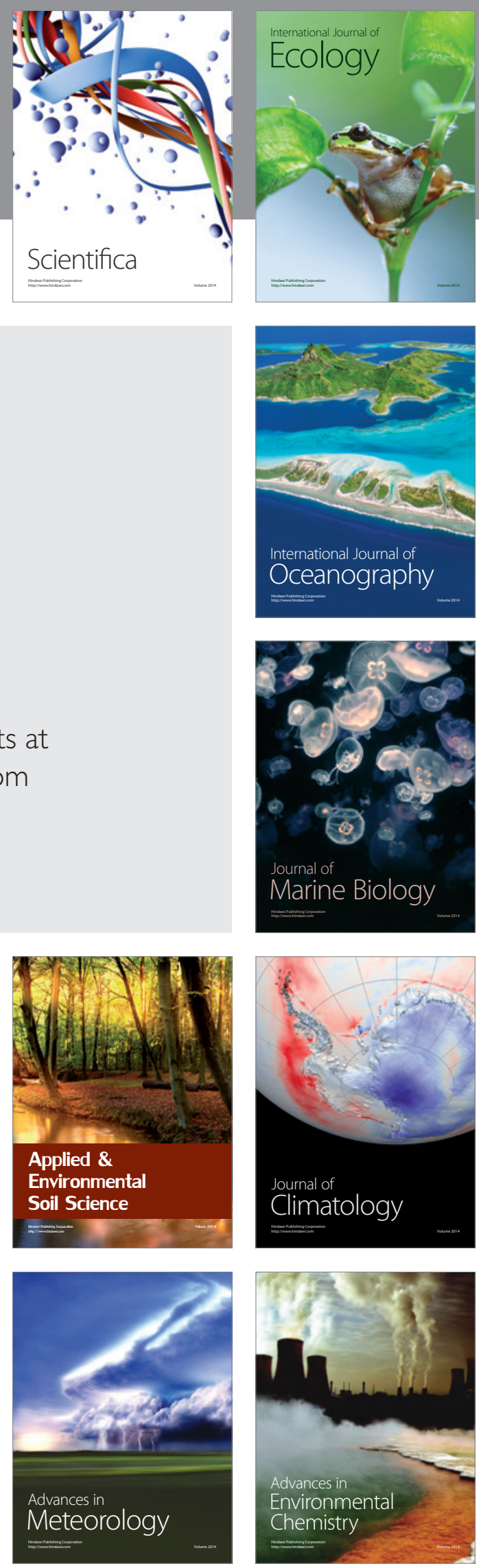